\title{
Resenha
}

\section{Glob(AL): biopoder e luta em uma América Latina globalizada}

\begin{abstract}
Alexandre Mendes*
NEGRI, Antonio; COCCO, Giuseppe. Glob(AL): biopoder e luta em uma América Latina globalizada. Rio de Janeiro: Record, 2005. 271 p.
\end{abstract}

No livro Glob(Al): Biopoder e Luta em uma América Latina Globalizada, Giuseppe Cocco e Antonio Negri realizam um valioso esforço teórico para criar uma gramática política renovada, que esteja afinada com as profundas mudanças que atravessam a região latino-americana, em especial a partir da democratização política e da inserção veloz no mundo globalizado.

Conceitos como democracia, representação, soberania, biopoder, biopolítica, interdependência, resistência, comum e poder constituinte são mobilizados para empreender uma leitura original sobre o passado latino-americano recente, com sua democracia sempre fugidia e bloqueada pelos pactos oligárquico-conservadores e, ao mesmo tempo, para lançar com criatividade possíveis caminhos e ferramentas para a construção da democracia no continente.

Com relação às numerosas e distintas análises existentes sobre o tema, duas inflexões "metodológicas" presentes no livro são fundamentais. A primeira, no marco de uma verdadeira ontologia da resistência, afirma o traço sempre constituinte e potente da liberdade. Os inúmeros êxodos, migrações, recusas e fugas, com seus múltiplos sujeitos - o escravo, o camponês, o nordestino, o trabalhador assalariado, informal etc. - constituiriam, longe de derrotas sempre reeditadas, as bases possíveis para a produção de uma democracia material, mestiça e colorida, nunca compreensível pelo modelo da social-democracia ou do gauchismo europeu. Uma democracia colorida e nômade face ao cromatismo sem fim da dominação racista. "Canudos venceu!", proclamam os autores.

O segundo deslocamento, operado no tormentoso espaço que abrange economia e democracia, defende a relação direta entre a potencialização das condições sociais da produção e de mobilização cooperativa dos trabalhadores (liberdade, expressão, conhecimento, cidadania e universalização dos direitos) e o desenvolvimento econômico da sociedade. Não há verdadeiro desenvolvimento sem democracia. Políticas de transferência de renda, de democratização da cultura e comunicação, de acesso ao conhecimento, de defesa das ações afirmativas e dos novos direitos da cidade, seriam exemplos dessa nova agenda política. "Construir riquezas e ter direitos deve se transformar na mesma coisa".

Nesse campo, por insistir em separar liberdade e igualdade, o liberalismo, mesmo em suas atuais vertentes, desmorona. Da mesma forma, o antigo sonho nacional-desenvolvimentista é desnudado como crescimento sem democracia, riqueza sem igualdade e produção econômica sem direitos. O resultado é claro para os autores: ditadura política culminando na hiperinflação e,

\footnotetext{
* Defensor Público do Estado do Rio de Janeiro, doutorando em Direito (UERJ), editor da Revista Lugar Comum: estudos de mídia, cultura e democracia e participante da rede Universidade Nômade.
}

Liinc em Revista, v.5, n.2, setembro 2009, Rio de Janeiro, p.288-289 - http://www.ibict.br/liinc 
em seguida, o neoliberalismo: falsa, desesperada e exaurida alternativa apresentada pelo biopoder como forma de manter o obstáculo à democracia.

$\mathrm{O}$ fracasso do passado inspira a esperança no presente. $\mathrm{O}$ "vento da democracia começa a se tornar impetuoso no subcontinente americano". A construção atual da democracia se torna possível, segundo Cocco \& Negri, exatamente no exercício contínuo das lutas sempre singulares pela emancipação e interdependência no continente, bem como através da nova dimensão do trabalho imaterial e da cooperação social. Se o desafio político aberto pela recente eleição de governos de esquerda passa pela relação inconclusa (de interlocução e ruptura) entre movimentos e governos, é o conceito de poder constituinte que se torna ao mesmo tempo evidente e enigmático.

Em tempos de crise global e generalizada do capitalismo, desvendá-lo é tarefa daqueles que, com coragem, abandonam velhas e dogmáticas fórmulas de pensar o mundo. Neste sentido, o livro Glob(al) não só é uma efetiva contribuição a essa nova empreitada, mas também expressão, ele mesmo das transformações políticas vivenciadas na América Latina em sua insubmissa "marcha da liberdade". 